\title{
The Effects of Government Ownership on Bank Lending
}

\author{
Paola Sapienza* \\ Northwestern University \& CEPR \\ This Draft: October 2002 \\ Forthcoming: Journal of Financial Economics
}

\begin{abstract}
This paper studies the effects of government ownership on bank lending behavior. Using information on individual loan contracts, I compare the interest rate charged to two sets of companies with identical characteristics borrowing respectively from stateowned and privately owned banks. State-owned banks charge lower interest rates than do privately owned banks to similar or identical firms, even if the company is able to borrow more from privately owned banks. State-owned banks mostly favor firms located in depressed areas and large firms. The lending behavior of state-owned banks is affected by the electoral results of the party affiliated with the bank: the stronger the political party in the area where the firm is borrowing, the lower the interest rates charged. This result is robust to including bank and firm fixed effects.
\end{abstract}

${ }^{*}$ I am indebted to Andrei Shleifer for guidance and encouragement. I also thank Alberto Alesina, Paul Armstrong-Taylor, Richard Caves, Riccardo DeBonis, Xavier Freixas, Anil Kashyap, Randy Kroszner, Patricia Ledesma, Anna Paulson, Luigi Zingales, an anonymous referee, and seminar participants at 1999 European Symposium in Financial Markets, NBER Universities Research Conference on Macroeconomic Effects of Corporate Finance, American Finance Association, and the Federal Reserve of New York for helpful comments and suggestions. Laura Pisani provided excellent research assistantship. All remaining errors are my responsibility. 
La Porta et al. (2002) document that worldwide, there is a large, pervasive government ownership of banks. In 1995 the average percentage of state ownership in the banking industry around the world was about 41.6 percent, and somewhat lower (38.5 percent) if we exclude former socialist countries. Mayer (1990) shows that bank financing is the main source of outside financing in all countries. Despite the prevalence of government-owned banks in many countries, the prominent role of banks in financing enterprises, and the importance of efficient financial markets for growth, there is very little evidence of the effects of government ownership on bank lending.

In this paper I use a unique dataset on state-owned banks in Italy, where lending by state-owned banks represents more than half of the total. By using data on interest rates charged on individual loans, the paper studies the efficiency in the allocation of credit of state-owned banks. Furthermore, I combine data on lending with the political affiliation of the bank and results in recent elections to study the impact of political power on bank lending behavior.

The debate concerning the role of ownership in banking is framed along the three alternative theories of state-ownership, social, political, and agency views. The social view (Atkinson and Stiglitz (1980)), which is based on the economic theory of institutions, suggests that state-owned enterprises (SOEs) are created to address market failures whenever the social benefits of SOEs exceed the costs. According to this view, government-owned banks contribute to economic development and improve general welfare (Stiglitz (1993)). In contrast, recent theories on the politics of government ownership (Shleifer and Vishny (1994a)) suggest that SOEs are a mechanism for pursuing the individual goals of politicians, such as maximizing employment or financing favored enterprises. The political view is that SOEs are inefficient because of the politicians' deliberate policy to transfer resources to their supporters (Shleifer (1998)).

The agency view shares with the social view the idea that SOEs may be created to maximize social welfare, but may generate corruption and misallocation (Banerjee (1997) and Hart, Shleifer, and Vishny (1997)). Agency costs within government bureaucracy may result in weak managerial incentives in SOEs. According to this view, the ultimate efficiency 
of SOEs depends on the trade-off between internal and allocative efficiency (Tirole (1994)).

These theories cannot be disentangled by looking at bank profitability: it is not clear whether government owned banks are less profitable because they maximize broader social objectives, because they have lower incentives, or because they inefficiently cater to politicians' wishes. The empirical strategy I use in this paper addresses these problems. Instead of looking at overall bank performance, where the mix of activities performed by banks might change under government ownership, I focus on the lending relations of the banks. The data I use include information on the balance sheets and income statements of a panel of over 37,000 Italian firms. The data are collected by Centrale dei Bilanci (CdB), an institution created to provide its members, mainly banks, with economic and financial information for screening Italian companies. For a large subset of the 37,000 companies, CdB members receive a numerical score, which CdB obtains by using traditional linear discriminant analysis, to identify the risk profile of the companies (Altman, 1968). I merge this information with data on the credit relations of the firms surveyed in the CdB database.

The information in this database is available to all the banks prior to lending and has proven to be very accurate in predicting the success or failure of a company (see Altman et al. (1994)). Since both privately owned and state-owned banks have access to the same information, I can use this system to check the differences in the credit policies of the various banks.

I look at the individual loan contracts of the two types of banks. I compare the interest rate charged to two sets of companies with identical scores which are borrowing either from state- or privately owned banks, or both. My main result is that, all else equal, state-owned banks charge lower interest rates than do privately owned banks. On average, the difference is about 44 basis points.

I claim that this difference can best be explained by the political view of state-owned firms. First, my results show that even companies that are able to access private funds benefit from cheaper loans from state-owned banks. Second, companies located in the south of Italy benefit more than companies located in the north from borrowing from state-owned banks, consistent with the view that political patronage is more widespread in the south 
(Ginsborg (1990)). This result remains true controlling for the presence of credit constraints. Finally, contrary to the social welfare maximizing view, state-owned banks are more inclined to favor large enterprises. Overall, my results support the political view of government ownership. However, I note that some of these results can also be consistent with some versions of the social view and the agency view. For example, one could argue that firms located in the south receive cheaper funds because a socially maximizing government wants to channel funds in depressed areas of the country. My findings that larger firms get cheaper funds may be also consistent with the agency view.

To further distinguish among the different theories, I analyze the relation between interest rates, the political affiliation of the bank, and electoral results. I find that the lending behavior of state-owned banks is affected by the electoral results of the party affiliated with the bank: the stronger the political party in the area where the firm is borrowing, the lower the interest rates charged. This result is not driven by omitted banks' and firms' characteristics, since I show that it is robust to including both bank and firm fixed effects.

Overall, my results support the political view of SOEs and suggest that state-owned banks serve as a mechanism to supply political patronage. These results relate to important policy debates. My finding show that government ownership of banks has distorting effects on financial allocation of resources. This is consistent with findings that widespread state ownership of banks is correlated with poor financial development (Barth, Caprio and Levine, 2000). In turn, a highly politicized allocation of financial resources may have deleterious effects on productivity and growth, as recent research by La Porta, Lopez-de-Silanes, and Shleifer (2002) shows.

The paper is organized as follows. The next section briefly outlines the theories of SOEs and their predictions. Section 2 provides a description of the institutional environment. Section 3 describes the data, the sample, and the methodology. Section 4 presents the empirical evidence. Section 5 concludes. 


\section{Theoretical issues}

The three main views of SOEs - social, agency, and political - have different implications for both the existence and the role of state-owned banks. The social view sees SOEs as institutions created by social welfare maximizing governments to cure market failures. According to this view, state- and privately owned enterprises differ because the first maximizes profits and the latter maximizes broader social objectives. In this literature, the reason for creating public financial institutions is the existence of market failures in financial and credit markets (Stiglitz and Weiss (1981), Greenwald and Stiglitz (1986)). Thus, creating state-owned banks or programs of direct credit has often been justified on the ground that private banks fail to take social returns into account. For example, private banks may not allocate funds to projects with high social returns or to firms located in specific industries (Stiglitz (1993)). Under the social theory, the objective function of state-owned banks should be to channel resources to socially profitable projects or to firms that do not have access to other funds.

The agency view shares with the social theory the idea that governments seek to maximize social welfare. Under the agency hypothesis, governments design public financial institutions to cure market failures. However, since SOEs maximize multiple nonmeasurable objectives, managers of SOEs have low-powered incentives (Tirole (1994)). ${ }^{1}$ Given the incentive problems associated with the control of SOEs, the agency view concludes that decisions on government in-house provision of public goods should depend on the trade-off between internal and allocative efficiency. Under this hypothesis, state-owned banks channel resources to socially profitable activities, but public managers may exert less effort (or divert more resources) than would their private counterparts. The agency view predicts that in general state-owned banks serve social objectives and allocate resources where private markets fail. However, public managers of state-owned banks may exert low effort or divert resources for personal benefits, for example, for career concerns, with an eye towards future job prospects in the private sector.

According to both the social and the agency view, the government role in the economy

\footnotetext{
${ }^{1}$ Low powered incentives are not always bad. Laffont and Tirole (1993) show that, under some circumstances, a concern for quality calls for low powered incentives.
} 
emerges and evolves to perform the economic functions that markets either cannot handle or cannot perform well. Fundamentally different, the political view is based on the assumption that politicians are self-interested individuals who pursue personal, political, and economic objectives rather than maximizing social welfare. The main objective of politicians is to maintain voting support. Hence, SOEs provide jobs for political supporters, and direct resources to friends and supporters (Shleifer and Vishny (1998)). According to this view, politicians create and maintain state-owned banks not to channel funds to economically efficient uses, but rather to maximize politicians' personal objectives.

Though the agency and the political views make very different assumptions about government's objectives, the difference in the empirical implications is not so clearly defined. The merit of the agency view is to show that misgovernance can exist even when the government has the best of intentions (see Banerjee (1997)). Under both views, we would observe some misallocation of resources, but for different reasons. The agency view claims that the misallocation takes place because managers shirk or divert resources for their private use, but under the political view, the misallocation of resources is the objective of politicians, rather than due to the lack of incentives. State-owned banks will divert resources to areas where there is more political patronage, will finance friends and supporters of politicians, and will maximize political support, e.g., maximize employment at the bank level or at other firms.

\section{State ownership of banks in Italy}

Though there are more privately owned banks than state-owned banks in Italy (864 compared to 117), in 1995 the percentage of total assets held by state-owned Italian banks was 58 percent, among the highest in the industrialized world. ${ }^{2}$ But, Italy is not unique in this dimension: most Continental European countries are similar (e.g., in Germany the proportion is 50 percent, in France, 36 percent). Latin American countries also show a very high percentage of state ownership. In fact, in a recent paper La Porta et al. (2002) show that worldwide, there is a large, pervasive government ownership of banks. In 1995 the average percentage of state ownership in the banking industry around the world was about 41.6

\footnotetext{
${ }^{2} \mathrm{I}$ consider foreign banks operating in Italy as being privately owned.
} 
percent, and somewhat lower (38.5 percent) if we exclude former socialist countries.

Data on Italian state-owned banks suggest that, in general, they have a different lending focus from privately owned banks. De Bonis (1998) shows that state-owned banks make more than 11 percent of their loans to state or local authorities (compared to 1.6 percent loaned by private banks). The percentage loaned to companies is similar between state- and privately owned banks (55.1 and 57.5, respectively), but no analysis has investigated the differences within each class of borrowers for the two groups of banks. De Bonis (1998) also finds that state-owned banks are less profitable in making loans than are privately owned banks. In 1995, the percentage of bad loans on bank capital for state-owned banks was 57.2, almost double of that of private institutions (30.2 percent).

The degree of political influence on state-owned banks is evident in the procedure used to appoint the chairpersons and top executives in state-owned banks. Until 1993, the appointments of the directors and management of the banks was made by a specific Parliamentary commission. ${ }^{3}$ For example, in 1992, this commission met three times: on October 30th they appointed 72 of chairpersons, vice-chairpersons, and CEO of state-owned banks; on December 1st they appointed other 26, and on December 30th an additional 33.

Over time there could have been differences in the level of political interference. Some authors (e.g., Barca and Trento (1994) and Ginsborg (1990)) claim that close personal ties between party leaders and the managers of SOEs were introduced after the mid 1950s. De Bonis (1998) claims that the management of state-owned banks became independent from the central government after 1993, when the public entities that previously owned the banks directly were transformed into foundations. Nonetheless, some observers believe that the practice of political appointments of top executives in state-owned banks has survived (e.g.,Visentini, 2000).

\footnotetext{
${ }^{3}$ Specifically, the Comitato Interministeriale per il Credito e il Risparmio (CICR), a permanent Parliamentary commission, in which the political groups are represented according to their relative strength in Parliament.
} 


\section{Data and Methodology}

In this study, I rely on several data sources. The two main databases come from Company Accounts Dataset (CAD) and the Credit Register (CR). CAD reports balance sheet and income statements for more than 50,000 Italian companies. CR collects information about any individual loan contracts over 80 million lire (about 41,300 Euro) granted by banks to any customer. This information is readily available to the CdB membership, which is mainly comprised of banks. Starting in 1991, CdB also developed what it called the Diagnostic System, which was designed to provide banks with a tool for quickly identifying the soundness of the companies included in the database. This system applies traditional linear discriminant analysis based on two samples of businesses of healthy and unsound companies. A numerical score is obtained from two discriminant functions. This score summarizes the "risk profile" of the business. This system has proven to be very successful: it correctly classified in the year immediately prior to distress 87.6 percent of healthy companies and 92.6 percent of unsound companies (see Altman et al. (1994)). Appendix I provides more details on the numerical score.

For each firm, the CR reports the amount of credit granted by each bank, together with the amount used (outstanding balance). In addition, 90 banks (accounting for over 80 percent of total bank lending) agreed to file detailed information about the interest rates charged on each loan. These data, collected for monitoring purposes, are highly confidential.

A subset of CR data includes all the companies that were surveyed for at least one year in CAD. Data on loan contracts are quarterly, but data on balance sheets and income statements are annual. Aggregate information on bank balance sheets and income statements comes from the prudential supervision statistical data, where it is reported on a quarterly basis. I constructed the data on the bank ownership by using the Bank of Italy legal classification prior to $1990 .^{4}$

I obtain local election results for three national elections, 1989, 1992, and 1994 from the

\footnotetext{
${ }^{4}$ Prior to 1990 all state-owned banks had a different legal status from private banks (either corporations and cooperatives). After 1990, all the state-owned banks' charters were modified by law and banks were transformed into corporations.
} 
archives of the Interior ministry. The local unit is the province (similar to U.S. counties). The archives provide the total valid votes and the votes collected by all the parties running the elections in each of Italy's 95 provinces.

I collect the data on political affiliation of the top management of the bank from newspapers. For 36 state-owned banks I am able to identify the political affiliation of the chairperson. Appendix II provides additional details about these data and the electoral data.

\section{A Privately owned and state-owned banks}

The data on loan contracts come from the subset of the CR and CAD datasets previously described. The sample period begins in 1991 and ends in 1995, because 1991 is the first year in which $\mathrm{CAD}$ distributed the information on the score to its members. I restrict my attention to privately owned and state-owned banks that file information about interest payments and are members of the CdB.

This criterion introduces a potential sample selection, since the banks that file interest rate information are generally larger than the average Italian bank. However, it turns out that this is not a problem for the sample of state-owned banks: the sample represents more than 90 percent of state-owned loans. I exclude small state-owned banks from the sample, but they are not the typical state-owned bank. Privately owned banks selected with these criteria are larger than the average privately owned bank, but because I use them as benchmark for comparing the behavior of state-owned banks, it is important that they are similar in size to the state-owned banks.

These selection criteria restrict the total number of banks to 85: 40 have always been privately owned; 43 are state-owned banks; and two are privatized during the period of observation.

Table 1 shows descriptive statistics of the banks in the sample. The median state-owned bank has a ratio of non-performing loans to total loans of 6.91 percent, as opposed to 5.25 percent for privately owned banks. The mean for the two sub samples is statistically different at 1 percent level of significance. State-owned banks also have a lower return on assets (0.34 for the median state-owned bank, as opposed to 0.51 for the median privately owned 
bank) and higher operating costs over assets (3.05 for the median state-owned bank, as opposed to 2.87 for the median privately owned bank). These differences in the sample reflect differences between state-owned and privately owned banks and represent a potential problem in comparing credit policies of these two sub-samples of banks.

\section{B Companies borrowing from privately owned and state-owned banks}

Ideally, I would like to compare the entire loan portfolio of state-owned and privately owned banks and, using the balance sheet and income statement information for the companies, compare the credit decisions of these two types of banks. Unfortunately, the information on the firms' characteristics is available only for a subset of the companies that receive credit from the banks.

To deal with this lack of information, I take a different approach. Instead of comparing the entire loan portfolio of state-owned and privately owned banks, I compare two matching samples of companies that borrow from state and privately owned banks, respectively. The advantage of using this approach is that I can compare the interest rate charged in the same period to the same company, or to very similar companies, by state- and privately owned banks (many firms have credit ties with both types of banks). Since state- and privately owned banks have access to the same information for evaluating these companies, any difference in the price of the loan is likely to reflect differences in the objective of the bank, rather than differences in the evaluation skills of the banks' loan officers.

To select the sample of companies in this study, I use the following criteria: from the sample of companies included in CdB, I select a subsample of companies that have a loan with at least one bank in the sample for at least one period and for which there is a numerical score. Because loan characteristics (collateral, etc...) may have an impact on loan rates (Petersen and Rajan, 1994, and Berger and Udell, 1994) I focus on homogenous loan contracts. I analyze credit line contracts, the most common loan contract in Italy in which banks set the amount of loan money granted and an interest rate. The loans analyzed here exclude long-term loans, collateralized, and subsidized loans. ${ }^{5}$.

\footnotetext{
${ }^{5}$ There are other characteristics of the relationship between banks and borrowers that I cannot control
} 
From this data I select the subset of companies that have been borrowing from stateowned banks. For each observation in this sample (company-bank-year) I identify a matching company that borrows from a privately owned bank in the same period. Whenever the company borrows in the same year from both state- and privately owned banks, I match the company with itself. If a company borrows only from state-owned banks, I choose a similar firm that borrows from privately owned banks in the same year. In these cases, I identify the matching company as a firm operating in the same industry and in the same geographical area (north, center, and south), with an identical risk profile (Altman's z-score (Altman, 1968, 1993)), and similar size (measured by sales). I also require that if the company that receives loans from state-owned banks is state-owned (privately owned), then the matching company is state-owned (privately owned) as well.

These selection criteria reduce the sample to a total of 6,968 companies, corresponding to 110,786 company-bank-year observations. 55,393 observations refer to borrowers of stateowned banks and 55,393 to borrowers of privately owned banks.

By construction, the companies that borrow from state- and privately owned banks have identical scores, operate in identical industries, and are located in the same geographical area. Table 2 shows the sample scores for the two sub-samples of companies.

The summary statistics on the two sub-samples of firms (Table 3) also show that the selected companies borrowing from state- and privately owned banks are very similar. None of the differences in the means of the relevant variables is statistically significant. In both sub-samples, the median firm has 58 employees, 21 billion lire in sales, 18 billion lire in assets and a coverage, interest expenses divided by EBITDA, of 1.47. The median firm has a leverage of 71 percent. I define leverage as the book value of short plus long term debt divided by sum of the book value of short plus long term debt and the book value of equity. Return on sales is slightly below 8 percent. The majority of the companies are privately for. Although the loan contracts included in the sample have homogenous characteristics, borrowers might have contemporaneous contracts with the bank (deposits, collateralized loans) that might affect the cost of the loan. Also, the quality of service or the probability of the loan to be revoked can vary across banks. Unfortunately, I cannot rule out any of these possibilities; therefore my results should be interpreted with these caveats in mind 
held. Seventy are state-owned companies.

\section{Empirical analysis}

\section{A Differences in interest rates}

To learn whether state- and privately owned banks behave differently, I examine the interest rate charged to similar companies by these two types of banks. I first compare the average interest rates charged by both types of banks and then present a regression analysis that controls for banks' and firms' characteristics.

Table 3 reports the average interest rate minus prime rate charged by both types of banks. I define the interest rate as the ratio of the quarterly payments made by the firm to its bank (interest plus fixed fees) to the firm's quarterly loan balance. Of course, this measure of interest rate overestimates the interest rate of a firm with a small average balance. For this reason, I eliminate the rates linked to credit lines with less than 50 million lire in average daily balance. The same criterion has been used by Pagano et al. (1998) and Sapienza (2002).

Column 3, table 3 presents the differences in the interest rates minus the prime rate for the two subsets of banks (i.e. column 2 minus column 1). For the overall sample, these comparisons show that for similar companies, the average interest rate charged by stateowned banks is lower than that charged by private banks. The differences are statistically significant in a $t$-test.

Table 3 also presents the differences in interest rates for various risk profiles of the companies, demonstrating that these differences are not driven by few outliers. Also, to make sure that the differences are not driven by any incorrect matching, panel B of Table 3 presents the same statistics for the subsample of firms that borrow from both state- and privately owned banks during the same year (the matching firm is self).

My main finding is that for any risk profile, the interest rate charged by state-owned banks is lower than that charged by privately owned banks. The difference in interest rates is statistically significant at 1 percent level. 
The average difference between the interest rates charged by private and state-owned banks is 23 basis points. However, the comparisons presented above are not conditioned on other characteristics of the banks, such as differences in size and riskiness of the portfolio. Table 1 shows that state- and privately owned banks are different in size, profitability, and riskiness. To address this issue, I use a regression model to estimate the difference in interest rates charged by the two types of banks.

I regress $r_{i k t}$, the relative interest rate charged at time $t$ by bank $k$ to company $i$ (defined as the interest rate minus the prime rate) on a dummy variable, $S T A T E_{k, t}$, that equals one if at time $t$ bank $k$ is a state-owned bank. The coefficient measures the impact of state ownership on interest rates. A negative (positive) value means that state-owned banks charge a lower (higher) interest rate than do privately owned banks. I also include several regressors to control for firms', market's, and banks' characteristics. Finally, I include a vector of time fixed effects and a vector of firm fixed effects. By using a firm fixed effect, I compare the interest rate charged by various banks to the same company.

Panel A, Table 4, reports the regression results. Heteroskedasticity-robust standard errors are shown in parentheses. I also adjust standard errors for within-year clustering. Column 1 reports the estimates of the interest rate regressed on the $S T A T E_{k, t}$ dummy and time and firm fixed-effects. These results are directly comparable to the simple differences in the last row of Table 3: state-owned banks charge interest rates 23 basis points lower than do privately owned banks.

As mentioned before, the coefficients measuring state ownership may capture specific characteristics of state-owned banks and local market structure. To overcome this problem, in columns 2 to 5 of Table 4, I include several other controls.

In column 2 I introduce a proxy for the size of the bank, measured by logarithm of bank's total assets. Aside for the part size plays in determining market concentration measures, a bank's size should affect prices according to the theoretical literature. For example, in a standard Cournot model with capacity constraints (increasing returns to scale), one can show that the bank with lower capacity would supply loans equal to capacity at a lower price than the other bank with higher capacity (see Tirole, 1989). Size may also reflect some implicit 
characteristics of the loan. Loans from large banks may carry an implicit guarantee of not being revoked, if large banks are perceived to be less likely to fail. Empirically, Sapienza (2002) finds that bank's size has a positive and significant effect on loan rates for a sample of privately-owned banks, after controlling for firms' characteristics. Column 2 of Table 4 confirm this result. All else equal, a one-standard-deviation increase in the logarithm of banks' assets leads to an increase of nearly 14 basis points in the interest rate. Since stateowned banks are generally larger than privately owned banks, the size of the coefficient of $S T A T E_{k, t}$ increases from .23 to.46 after I control for banks' size, suggesting that the mean differences in Table 3 underestimate the impact of state ownership.

In column 3 of Table 4 I include two other controls in the regression. First, I include a measure of market concentration (the Herfindahl-Hirschman Index on loans) as many studies have identified a positive relationship between market concentration and prices (Berger and Hannan (1989) and Hannan (1991). Another potential problem in my basic regression is that the state-ownership dummy captures the fact that banks with a higher proportion of nonperforming loans charge lower rates. For example, riskier banks may offer loans of inferior quality, with higher probability of being revoked. For this reason, I include a measure of the riskiness of the bank (the percentage of non-performing loans).

The Herfindahl-Hirschman Index (HHI) on loans has the predicted effect. One standard deviation increase in HHI increases interest rates by 7 basis points. Surprisingly, the effect of the percentage of non performing loans is positive and significant. A one standard deviation increase in the percentage of non-performing loans causes a 13 basis points increase in interest rates. The regression predicts that, other else equal, a firm would save 50 basis points on loans from state-owned banks.

Consistent with the benign view of government, state-owned banks may forego exploiting market power when they possess it, while private ones will not. In fact, in column 4 I consider this possibility and re-estimate the regression, interacting the state-ownership dummy with the HHI. The results show that state-owned banks do in fact exploit market concentration less than otherwise similar private banks. Moving from the area with the lowest HHI to the area with the highest HHI private banks increase rates by 63 basis points, while state-owned 
banks increase rates by 44 basis points. This difference in behavior does not explain the systematic difference found between private and state-owned banks rates. First, the results show that state-owned banks exploit market power, only to a lesser extent than private banks. Second, the difference is small, in the province with the median HHI, everything else being equal, state-owned banks rates are lower than private banks rates by 6 basis points. Finally, the coefficient of the state-ownership dummy remains statistically and economically significant. After controlling for differences in market power exploitation, I find a difference of 44 basis points in rates charged between private- and state-owned banks.

As a further check for robustness, the specification in column 5 introduces the size of the firm (measured by logarithm of sales) and score. Although both the coefficients of the size of the firm and of the numerical score are statistically significant and have the right sign, the size of the estimated state ownership dummy does not change. ${ }^{6}$

One potential worry is that the results may be entirely attributable to unobservable firms' characteristics that may be changing over time. If that is the case the firm fixed effect is not fully controlling for this. To address this point, however, I can use one important feature of my data. I constructed the sample in such a way that a large percentage of companies in the sample receive loans from both state- and privately owned banks during the same year. To ensure that the results presented above hold for the companies that borrow from both types of banks at the same time, I re-estimate the regression model for this subsample of companies only. Panel B, Table 4, presents the results, which show a negative and significant coefficient for the $S T A T E_{k, t}$ dummy. All else equal, firms that raise money from both state-owned and private banks pay interest rates to state-owned banks that are lower by 44 basis points, confirming that the results cannot be attributable to unobservable firms' characteristics.

\section{B Discussion}

Table 4 shows that when I control for firms' and banks' characteristics, state-owned banks charge interest rates that are 44 basis points lower than those charged by comparable privately

\footnotetext{
${ }^{6} \mathrm{I}$ have also estimated some alternative specifications that include, among the regressors, other firms' control variables (i.e. leverage and profitability). The substantive results (unreported) are unchanged.
} 
owned banks.

This result supports many alternative hypotheses. First, consistent with the political view, state-owned banks may be charging lower interest rates to some firms because this responds to the politicians' objectives. For example, the firms that benefit from lower rates may be political supporters of the politicians.

Even if politicians maximize social welfare, managers of state-owned banks may lack the ability to screen firms. If bank managers systematically make mistakes in pricing loans, in equilibrium we observe only public loan contracts with lower interest rates, because the entrepreneurs will choose the contracts with the lowest interest rates. Also, managers of state-owned banks may be diverting banks' resources to their own benefit, favoring firms that bribe them or offer other types of benefits in exchange (e.g., future jobs). These latter two interpretations support the predictions of the agency view.

Are the results in Table 3 and 4 consistent with the social view? One problem with answering to this question is that the social view is pretty vague on the specific social welfare maximizing tasks that a state-owned bank is likely to perform. So, in the remaining paragraphs of this section, I will explore several potential objectives of state-owned banks according to the social view.

One way to explain the difference in interest rates is to claim that state-owned banks are either more efficient than privately owned banks or have lower costs, and thus are able to charge lower interest rates. During the period of observation, regulation and tax laws are identical for both state- and privately owned banks, so the argument that state-owned banks are more efficient in making loans should be based on the fact that state-owned banks are better managed organizations. The data do not confirm this hypothesis. It is well documented in the literature that state-owned Italian banks are less efficient than their private counterparts (see Martiny and Salleo (1997)). Table 1 confirms this fact for my sample.

The central prediction of the social view is that to cure market failures benevolent public banks are willing to lend to companies at lower interest rates. According to this view, stateowned banks favor enterprises that find it difficult or too expensive to raise capital from 
private banks. This argument assumes implicitly that state-owned banks make loans to companies with positive net present value (NPV) that are unable to raise capital from other sources. As it turns out, the data contradict this hypothesis.

The results in Table 4, Panel B show that state-owned banks charge lower interest rates even if the firm is able to raise capital from alternative sources. However, one could argue that these companies are rationed in terms of the funds they get from the private banks. To consider this possibility, I look at the ratio of the outstanding balance to the available amount (credit line) offered by privately owned banks. To prove that these companies are rationed, I must show that the outstanding balance is equal to the credit line. In fact, on average, the companies that borrow from privately owned banks have a percentage of loan use below 14 percent, suggesting that they could borrow larger amounts from privately owned banks. To further explore this issue, I restrict the sample to companies that borrow from both state-owned and private banks and have unused credit lines with private banks. The estimates (not reported) confirm the previous results. In Table 4, Panel C I also check whether firms that use a bigger fraction of their line of credit from private banks (and thus are more constrained) receive a bigger discount from state-owned banks. In column 1, 2, and 3 of Table 4, Panel C I report the results of the baseline regression where I add a new dummy that is equal to one if the bank is state owned and if the firm has an average percentage of used credit from private banks that exceeds a given threshold. As thresholds, I use 15 percent (75th percentile), 37 percent (95th percentile), and 72 percent (99 percentile). All the reported results show that the new dummy has a positive and insignificant coefficient. These findings suggest that the firms receiving lower rates from state-owned banks are able to raise capital form other private banks.

An alternative scenario consistent with my findings may support the social view. The government could wish to subsidize certain firms (e.g., firms that have difficulty accessing capital) by reducing the firm's average cost of capital. However, to maintain incentives, the government might want the firm to face the market interest rate at the margin. In this case, the government might offer a loan below the market rate for less than the full size of the project. The initial loan granted by the state-owned bank could then trigger more loans by 
private banks. Unfortunately, I am not able to test this hypothesis with my data because I do not have information on when the loans are initiated.

Concluding, the results presented in Table 4 are consistent with all the three views of SOEs.

\section{Sub-sample analysis: Geographic location and firm size}

To further investigate the behavior of state-owned banks and distinguish among the different theories, I study whether there is some class of borrowers that has a greater advantage in borrowing from state-owned banks. I look at two different dimensions: geographical location and size of the companies. I focus on the subsample of firms that receive loans from both state-owned and private banks. By doing this, I exclude firms that may face it difficulties obtaining loans in the private market.

As a first approximation, Table 5 presents the average interest rates charged by stateowned and private banks to the firms that borrow from both types of banks. The first three rows divide the sample according to the geographical location of the companies. The differences between the interest rates charged by private banks and state-owned banks suggest that companies located in the south of Italy benefit more than do other companies from borrowing by state-owned banks, even when they have access to private funds.

Table 6 looks at the same issue from within a regression framework. Table 6 presents the results of regression (1) including an interaction between companies' location and the $S T A T E_{k, t}$ dummy. For firms located in northern Italy (the omitted indicator), borrowing from state-owned banks saves 44 basis points, all else equal. For firms located in the south, a relationship with the state-owned bank would save them 75 basis points. This finding is consistent with Alesina, Danninger, and Rostagno (1999), who find that public employment in Italy is used as a subsidy from the north to the less wealthy south.

It is hard to reconcile this result with the incentive view. There is no particular reason why the managers of state-owned banks should have weaker incentives when they price loans to firms located in the south.

By contrast, both the social and the political views support the fact that state-owned 
banks apply higher discounts to firms located in the south of the country. The south of Italy is the poorest part of the country with an unemployment rate four times higher than in the center-north. For at least fifty years the south has been the focus of regional development policy, with massive capital inflows and real income transfers from the government. Lower interest rates to southern firms are consistent with a policy of subsidization, aimed at stimulating the southern regions. ${ }^{7}$ On the other hand, in the south the practice of political patronage is more widespread than in the north. Southern politics in Italy is largely organized around the distribution of patronage (see Golden (2001) and Ginsborg (1990)). This evidence suggests that there is another reason why firms located in the south are favored by the interest rate policy of state-owned banks: such favorable terms may be due to state-owned banks pursuing political objectives.

Table 5 also reports the differences across firm size in the interest rates charged by state- and privately owned banks. The results show that on average, the largest firms have more advantages in borrowing from state-owned banks. The difference between the interest rates charged by privately owned and state-owned banks is higher for the companies in the largest quintile. The relation across quintiles is nearly monotonic, but the differences are not statistically significant across quintiles.

Table 7 looks at the same issue in a regression framework. The results confirm that stateowned banks favor larger enterprises. The reduction in interest rates applied to companies in the largest quintile (the omitted indicator) by central government-owned banks is around 55 basis points. Firms in the smallest quintile that borrowing from state-owned banks save about 41 basis points, all else equal.

This result does not support the social view. If market imperfections prevent firms from raising money, then the benevolent state-owned banks should charge relatively lower interest rates to small companies that are more likely to be credit rationed. ${ }^{8}$ Instead, the

\footnotetext{
${ }^{7}$ The fact that these subsidization policies have systematically failed to close the gap between the centernorth and the south raises some doubts on the rationale of the development policy for the south. Nonetheless, perhaps ex-ante the government undertook these policies to maximize social welfare.

${ }^{8}$ Other evidence against the social view is that state-owned banks do not favor any particular industry. In another (unreported) regression I look at differences in interest-rate discounts across industries. I use the Rajan and Zingales (1998) measure of external financial dependence and check whether firms in industries
} 
results appear to support both the agency view and the politicians view. Managers of stateowned banks who lack incentives may be more prone to favor larger enterprises because their personal rewards are likely to be higher (e.g., a career in a larger firm is more valuable than one in a smaller firm). At the same time, state-owned banks may favor large enterprises, because state-owned banks are interested in maximizing a larger political consensus.

To sum up, while the social view and the incentive view alone can explain some results, the only interpretation consistent with both results is the political view of SOEs.

\section{Electoral results, party affiliation, and lending behavior}

To clarify the relationship between politicians' objectives and the lending behavior of stateowned banks, I collect data on the political affiliations of the top executives of state-owned banks. Ideally, I would like to link the credit policy of the bank to the political affiliation or voting behavior of the beneficiaries of the loans. Unfortunately, this information is not publicly available. Instead, I use the voting record of the province where the borrower is located. Although this is an approximation, it provides new insights on the influence of politics on SOEs.

Because I am interested in the relationship between the party affiliation of state-owned banks and lending behavior in this section I focus only on the subsample of firms that borrow from state-owned banks. I determine the political affiliation of 36 state-owned banks in my

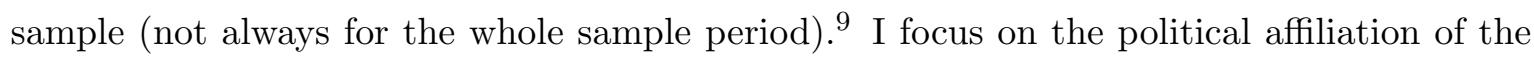
chairpersons. I do so because in Italian state-owned banks, the chairperson has strategic tasks and often acts as the CEO. Overall, in my sample the affiliation of the chairperson is linked to five different parties (See Appendix II for details). The political affiliations of the chairperson of the state-owned banks are relatively stable over time. In only four of the 36 banks does the political affiliation change during the sample period.

I use provincial electoral results from three national elections (1987, 1992, and 1994). that are more dependent on outside funds receive cheaper loans from state-owned banks. In contrast to the social view, the results do not support this hypothesis.

${ }^{9}$ The final sample is reduced to 108 state-owned-bank-year observations corresponding to 26,698 companybank(state-owned)-year observations. 
For each observation in the dataset I create a new variable that signifies the local political strength of the party. This variable is equal to the ratio of votes received by the party affiliated to the bank's chairperson in the geographical area in which the firm borrows over the total valid votes in the same geographical area. The geographical areas are the 95 Italian provinces. The electoral results are from the previous national election. ${ }^{10}$ For example, the chairman of Banco di Roma in 1991 was affiliated with the Christian Democrats. In 1991, Banco di Roma lent to 771 firms in my dataset. These firms were located in 55 different provinces. For each of these observations, I measure the local political strength of the party as the percentage of votes received by Christians Democrats in the province in which the firms are borrowing.

The variation in my measure of local political strength of the party has two different sources. First, because there are coalition governments, banks are affiliated to five different parties over the sample period. Some banks are affiliated with stronger parties, others with weaker parties. Second, because there is enough variation in electoral results across provinces (see Appendix II, for sample statistics), the local political strength of the party differs across provinces for those banks that lend in several provinces. In the example of Banco di Roma, the average provincial party strength of Christian Democrats (based on 1987 elections) was 33 percent, with a minimum of 8 percent and a maximum of 52 percent.

Table 8 reports how interest rates charged to borrowers of state-owned banks change according to the political strength of the party affiliated to the bank.

The dependent variable is the interest rate charged to firm $i$ by bank $k$ at time $t$ minus the prime rate at time $t$. The local political strength of the party is the percentage of votes received by the party to which the chairperson of the state-owned bank is affiliated in the province in which the firm is borrowing. The regression also includes controls at the bank level (size and percentage of non-performing loans), the concentration of loans (HHI on loans), size of the firm, and year and firm dummies. I correct the standard errors for within-year clustering.

The first column of Table 8 reports the results for all the state-owned bank-firm-year

\footnotetext{
${ }^{10}$ I use 1987 electoral results for loans in year 1991, 1992 electoral results for loans in years 1992 and 1993 , and 1994 electoral results for loans in 1994 and 1995.
} 
observations for which I was able to find a political affiliation for the chairperson of the bank. The political strength of the party has a negative and significant effect on the interest rate charged to borrowers. One standard deviation increase in the political strength of the party decreases interest rates by an average of two basis points. The effect is small, but not negligible. For example, the largest party in my sample has a variation in political strength between 7 percent (Bolzano) and 52 percent (Avellino). The results imply that a borrower in Avellino pays 9 basis point less than a borrower in Bolzano. All the other variables have the predicted sign.

However, this effect may be underestimated for two possible reasons. First, the chairperson's political affiliations in years 1994 and 1995 may be measured with noise due to changes in the practice of appointing top executives in state-owned banks and to political scandals. Second, the national electoral results are not a good measure of party strength for local government owned banks.

In column 2 of Table 8, I restrict the sample to the period 1991-93. After 1993, major political parties were beset by scandals. They underwent far-reaching changes, which resulted in the wholesale turnover of the existing political class and the dissolution of the major political parties. During the same period, a campaign by the judiciary made significant inroads in uncovering major financial scandals involving several state-owned banks. In fact, eight of the state-owned banks in my sample were involved in frauds or bribery scandals, resulting in the resignation of several of the top executives and board members.

These changes affect my regressions in two ways. First, for the year 1994 and after, I was not able to determine more than a very few political affiliations in the banks. Most of the previously appointed chairpersons remained in charge, even though their party disappeared. Some chairpersons were convicted and temporarily replaced by the vice-chairperson who was often affiliated with a party that had also disappeared. In general, the active parties made very few new appointments after 1993. This fact explains the relatively small size of my sample for the years 1994 and 1995.

Second, because of the turmoil of the political parties, some authors (e.g., De Bonis, 1998) claim that the management of the banks became slowly more independent from politics or 
had no clear guidance from politicians in making decisions. For example, Piazza (2000) analyzes nonvoluntary turnover in Italian state-owned banks in 1994-1999. He finds that there is a weak link between electoral dates and chairmen turnover between 1994-96, but not in the subsequent period. For both reasons, in column 2 of Table 8 , I check whether the results change if I drop the observations for year 1994 and beyond. I find that the results are substantially the same.

I measure the political strength of the party using national election data. However, my sample contains two types of state-owned banks: national government-owned banks and local government-owned banks. In national banks, the appointments of the top executives are influenced by the party leaders of the ruling coalition. By contrast, the appointment of the management of local banks is decided by local bureaucracies (e.g., by the local branch of the party, the mayor of the largest city, and other such local politicians) (see De Bonis (1998)). If such is the case, local government banks may be affected by local elections and the national electoral results may not be a good measure of the strength of the local political class.

To address this issue, in column 3 of Table 8 I re-estimate the regression only for the subsample of firms (17,671 observations) that borrow from national banks. The local strength of the political party to which the bank is affiliated has a stronger negative effect on the subsample of firms that borrow from national state-owned banks. A one-standard-deviation increase in political strength decreases the interest rate by 3.5 basis points. The effect is statistically significant at the 1 percent level. The fact that the coefficient is larger than in columns 1 and 2, as predicted, suggests that my measure of party strength is doing a good job of measuring the degree of influence of political parties on state-owned banks.

National banks lend in different provinces. Therefore, when I restrict the sample to national banks, I can introduce a dummy at the bank level. By using a bank fixed effect, I can use a bank that lends in a given province as a control for itself in a different province. Thus, I can compare the interest rate charged by the same bank in two different provinces, and how it changes according the political strength of the party to which the bank is affiliated. I do this in column 4 of Table 8. The coefficient of local political strength of the party measures 
how interest rates change according to the electoral results of the party that appointed the chairman of the bank. For example, when I compare a bank affiliated with the Christian Democrats I find that interest rates are reduced by 12.5 basis points in Avellino compared to Bolzano, all else equal. This result suggests that the effect measured in Table 8 is not driven by some omitted bank's characteristics in the regression.

The results of this section provide strong evidence for the political view of SOEs and suggest that state-owned banks are a mechanism for supplying political patronage. In areas in which the political party that runs the state-owned banks is stronger, borrowers get a higher discount than other areas. The effect is statistically significant and robust across all regressions.

\section{Conclusions}

The results of this paper show that state-owned banks charge systematically lower interest rates to similar or identical firms than do privately owned banks. This result is strong and statistically significant. Firms that borrow from state-owned banks pay an average of 44 basis points less than do firms that borrow from private banks. This finding is robust to various specifications. It remains true even if the firms are able to borrow from, and have unused credit lines with, private banks.

This initial finding can be explained by both the agency and political views of SOEs. To test whether the evidence supports the social view, one has to articulate potential hypotheses from this theory. A first hypothesis is that state-owned banks are able to charge lower rates because either they are more efficient or have lower costs. The data do not confirm this hypothesis. An alternative prediction from the social view is that state-owned banks lend to firms for which raising capital from private banks is either difficult or too expensive. Restricting the sample to firms that borrow from both state-owned banks and private banks still results in a significant interest rate differential of 44 basis points. This result holds controlling for the percentage of the credit lines used in private banks, thus ruling out the possibility that state-owned banks lend to credit constrained enterprises. Thus, the data do not seem to support the social view unless one posits that state-owned banks attempt to 
reduce the average cost of capital of certain firms, while still allowing firms to face market interest rates at the margin.

The next step in distinguishing among the three hypotheses was to examine interest rate differentials across regions and firm sizes. Both the social and political views would support the fact that state-owned banks apply higher discounts in southern Italy, which is poorer and characterized by widespread political patronage. The agency theory cannot readily account for this. Focusing on firm size, interest rates charged by state-owned banks are lower the larger the firm, which counters the social view, but would be consistent with the political and agency view.

Finally, I examine the relationship between the party affiliation of the top management of state-owned banks, electoral results of the party, and lending behavior. I use data on the political appointments of the chairpersons of state-owned banks to compare interest rates across state-owned banks. I found that party affiliation of state-owned banks' chairpersons does have a positive impact on the interest rate discount given by state-owned banks in the provinces where the associated party is stronger. The stronger the party controlling the bank in the area, the lower the interest rate charged. This result provides evidence that state-owned banks are a mechanism for supplying political patronage. In sum, while the agency and social views explain some of the evidence, these theories cannot account for all the results. The political view is the only interpretation consistent with all the results.

Taken as a whole, these results provide consistent, strong evidence in favor of the political view of SOEs.

The obvious question is how generalizable these results are to other borrowers outside the sample. The limited sample that I use in this paper requires some words of caution. Since I do not observe the banks' entire loan portfolio, I cannot rule out the possibility that stateowned banks are also addressing other objectives. My results do not imply that incentives and social goals never matter, only that the political view can explain some of the behaviors of state-owned banks.

In a broader context, it may be argued that these results provide an explanation of the observed negative correlations between government ownership of banks and financial 
development (Barth et al., 2000), and economic growth and productivity (La Porta et al., 2002). Furthermore, since political patronage may be even more prevalent in the developing world than in Italy, the case for state ownership of banks is significantly weakened. 
Table 1:

\section{Summary statistics: the banks' sample}

Panel A shows summary statistics for the sample of privately owned banks (banks-years). Panel B shows summary statistics for state-owned banks. Total Assets is the bank's total assets. Loans include all the bank's loans. Return on Assets is earnings over Total Assets. Operating costs include wages and other operating costs.

A: Privately owned banks

\begin{tabular}{lcccccc}
\hline \hline Variable & Mean & Median & Std Dev. & Min & Max & Obs. \\
\hline Total assets (Bill.) & 11,856 & 6,318 & 16,674 & 186 & 110,531 & 192 \\
Total loans (Bill. of lire) & 4,917 & 2,570 & 6,604 & 80 & 44,820 & 192 \\
Percentage of loans over total assets & 42.90 & 43.00 & 5.14 & 30.00 & 56.00 & 192 \\
Percentage of non-performing loans over total loans & 6.14 & 5.25 & 4.02 & 1.42 & 23.63 & 192 \\
Return on assets & .46 & .51 & .62 & -6.47 & 1.28 & 192 \\
Operating costs over total assets & 3.04 & 2.87 & .78 & 1.56 & 5.96 & 192 \\
\hline \hline
\end{tabular}

B: State-owned banks

\begin{tabular}{lcccccc}
\hline \hline Variable & Mean & Median & Std Dev. & Min & Max & Obs. \\
\hline Total assets (Bill.) & 27,314 & 6,070 & 40,192 & 547 & 188,944 & 199 \\
Total loans (Bill. of lire) & 12,292 & 2,586 & 18,750 & 218 & 79,011 & 199 \\
Percentage of loans over total assets & 41.75 & 42.00 & 7.59 & 24.00 & 70.00 & 199 \\
Percentage of non-performing loans over total loans & 8.41 & 6.91 & 6.23 & 1.63 & 39.55 & 199 \\
Return on assets & .28 & .34 & .73 & -7.19 & 1.32 & 199 \\
Operating costs over total assets & 3.05 & 3.05 & .65 & 1.73 & 5.65 & 199 \\
\hline \hline
\end{tabular}


Table 2:

\section{Summary statistics: the companies' sample}

The table presents summary statistics for the two sub-samples of company-bank-year. Panel A shows the summary statistics for the subsample of companies that borrow from privately owned banks (company-bank-year). Panel B shows the summary statistics for the companies that from state-owned banks. Total Assets is beginning of year total assets in Billions Lira. Sales is beginning of year sales in Billions Lira. Employees is the number of employees at the beginning of the year. Return on sales is Earning before Interest, Taxes, and Depreciation (EBITDA) over sales. Age is the number of years since incorporation. Leverage is book value of short- plus long-term debt divided by book value of short- plus long-term debt, plus book value of equity. Coverage is interest expenses divided by $E B I T D A$ (I truncate values above 100 at 100 and values below zero at zero).

A: Companies borrowing from privately owned banks

\begin{tabular}{lcccc}
\hline \hline Variable & Mean & Median & Std Dev. & Obs. \\
\hline Total assets (Bill.) & 101 & 18 & 546 & 55,393 \\
Sales (Bill.) & 108 & 21 & 654 & 55,393 \\
Employees & 231 & 58 & 928 & 54,782 \\
Return on Sales & 8.48 & 7.98 & 7.25 & 54,799 \\
Age & 25 & 18 & 36 & 55,168 \\
Leverage & 68.11 & 70.69 & 17.59 & 54,638 \\
Coverage & 1.85 & 1.47 & 2.56 & 55,351 \\
\hline \hline
\end{tabular}


B: Companies borrowing from state-owned banks

\begin{tabular}{lcccc}
\hline \hline Variable & Mean & Median & Std Dev. & Obs. \\
\hline Total assets (Bill.) & 101 & 18 & 547 & 55,393 \\
Sales (Bill.) & 108 & 21 & 654 & 55,393 \\
Employees & 231 & 58 & 928 & 54,789 \\
Return on Sales & 8.51 & 7.95 & 7.37 & 54,817 \\
Age & 25 & 18 & 36 & 55,173 \\
Leverage & 68.12 & 70.71 & 17.60 & 54,646 \\
Coverage & 1.86 & 1.47 & 2.63 & 55,349 \\
\hline \hline
\end{tabular}


Table 3:

\section{Difference in interest rates charged by state-owned and privately owned banks}

I define the interest rate as the ratio of the quarterly payment (interest plus fees) paid by the firm to the bank to its quarterly average balance minus the prime rate. The numerical score describes the risk profile of the company (see details in Appendix I). In the second column, the interest rate refers to the subsample of companies borrowing from state-owned banks. In the third column, the interest rate refers to the companies borrowing from privately owned banks. The difference is the average difference between the second column (interest rates charged by state-owned banks) and the third column (interest rates charged by privately owned banks). For the difference, I test the statistical significance using the $t$ statistic with reference to a mean of zero. ***indicates statistically significant at the 1-percent level, ** indicates statistically significant at the 5 -percent level.

Panel A: Whole sample

\begin{tabular}{lcccc}
\hline \hline SCORE: & State owned banks & Privately owned banks & Difference & Obs. \\
\hline High security & 2.53 & 2.75 & $-.22^{* * *}$ & 1,420 \\
Security & 2.75 & 2.97 & $-.22^{* * *}$ & 15,262 \\
Vulnerability & 2.84 & 3.25 & $-.41^{* * *}$ & 409 \\
High vulnerability & 3.05 & 3.28 & $-.24^{* * *}$ & 11,743 \\
Uncertainty between vulnerability and risk & 3.18 & 3.43 & $-.25^{* * *}$ & 13,471 \\
Risk of bankruptcy & 3.36 & 3.58 & $-.22^{* * *}$ & 10,472 \\
High risk of bankruptcy & 3.69 & 3.80 & $-.11^{* *}$ & 2,616 \\
\hline All borrowers & 3.07 & 3.31 & $-.23^{* * *}$ & 55,393 \\
\hline \hline
\end{tabular}


B: Firms borrowing from both state-owned and privately owned banks

\begin{tabular}{lcccc}
\hline \hline SCORE: & State owned banks & Privately owned banks & Difference & Obs. \\
\hline High security & 2.52 & 2.74 & $-.22^{* * *}$ & 1,360 \\
Security & 2.72 & 2.94 & $-.22^{* * *}$ & 13,373 \\
Vulnerability & 2.85 & 3.26 & $-.41^{* * *}$ & 394 \\
High vulnerability & 3.02 & 3.27 & $-.24^{* * *}$ & 10,248 \\
Uncertainty between vulnerability and risk & 3.15 & 3.40 & $-.25^{* * *}$ & 11,899 \\
Risk of bankruptcy & 3.33 & 3.54 & $-.21^{* * *}$ & 9,184 \\
High risk of bankruptcy & 3.66 & 3.79 & $-.13^{* *}$ & 2,438 \\
\hline All borrowers & 3.05 & 3.27 & $-.23^{* * *}$ & 48,896 \\
\hline \hline
\end{tabular}


Table 4:

\section{Interest rates charged by state-owned and privately owned banks}

The dependent variable is the interest rate charged to firm $i$ by bank $k$ at time $t$ minus the prime rate at time $t$. $S T A T E_{k, t}$ is a dummy variable equal to one if at time $t$ bank $k$ is a state-owned bank. I measure the size of the bank by logarithm of total assets. The percentage of non-performing loans is the ratio of non-performing loans over total loans. I measure market concentration at the province level by the Herfindahl-Hirschman Index (HHI) on total banking lending. Size of the firm is the logarithm of sales. All regressions include year and firm dummies. Heteroskedasticity robust standard errors are in brackets. The standard errors are corrected for within-year clustering. The table also reports the p-value of an F-test for the hypothesis that the joint effect of all the variables equals zero. Panel A reports the results for the whole sample. Panel B and C report the results for the subsample of firms that borrow from both state-owned and privately owned banks. 
Panel A:

\begin{tabular}{|c|c|c|c|c|c|}
\hline & $(1)$ & $(2)$ & $(3)$ & $(4)$ & $(5)$ \\
\hline \multirow[t]{2}{*}{ State $_{k, t}$} & $-0.2378^{* * *}$ & $-0.4589^{* * *}$ & $-0.5019 * * *$ & $-0.4417 * * *$ & $-0.4424^{* * *}$ \\
\hline & $(0.0274)$ & $(0.0166)$ & $(0.0180)$ & $(0.0218)$ & $(0.0218)$ \\
\hline \multirow[t]{2}{*}{ Size of the bank } & & $0.1936^{* * *}$ & $0.1730^{* * *}$ & $0.1723^{* * *}$ & $0.1728^{* * *}$ \\
\hline & & $(0.0078)$ & $(0.0037)$ & $(0.0041)$ & $(0.0040)$ \\
\hline \multirow[t]{2}{*}{ Percentage of non performing loans } & & & $0.0337^{* * *}$ & $0.0338^{* * *}$ & $0.0336^{* * *}$ \\
\hline & & & $(0.0014)$ & $(0.0014)$ & $(0.0015)$ \\
\hline \multirow[t]{2}{*}{ Concentration of loans (HHI) } & & & $2.6681^{* * *}$ & $3.0753^{* * *}$ & $2.8267^{* * *}$ \\
\hline & & & $(0.4417)$ & $(0.3514)$ & $(0.4197)$ \\
\hline \multirow[t]{2}{*}{ Concentration of loans if State $_{k, t}=1$} & & & & $-0.8677^{* * *}$ & $-0.8561^{* * *}$ \\
\hline & & & & $(0.3223)$ & $(0.3183)$ \\
\hline \multirow[t]{2}{*}{ Size of the firm } & & & & & $-0.2453^{* * *}$ \\
\hline & & & & & $(0.0051)$ \\
\hline \multirow[t]{2}{*}{ Score of the firm } & & & & & $0.0365^{* * *}$ \\
\hline & & & & & $(0.0081)$ \\
\hline Firm fixed effect & yes & yes & yes & yes & yes \\
\hline Time fixed effect & yes & yes & yes & yes & yes \\
\hline Observations & 110,786 & 110,786 & 110,752 & 110,752 & 110,752 \\
\hline Adjusted R-squared & 0.407 & 0.420 & 0.425 & 0.425 & 0.428 \\
\hline \multicolumn{6}{|l|}{ p-value of F-test for total } \\
\hline effect equal to zero & 0.0000 & 0.0000 & 0.0000 & 0.0000 & 0.0000 \\
\hline
\end{tabular}


Panel B:

\begin{tabular}{|c|c|c|c|c|c|}
\hline & $(1)$ & $(2)$ & $(3)$ & $(4)$ & $(5)$ \\
\hline \multirow[t]{2}{*}{ State $_{k, t}$} & $-0.2293^{* * *}$ & $-0.4510^{* * *}$ & $-0.4980^{* * *}$ & $-0.4374^{* * *}$ & $-0.4376^{* * *}$ \\
\hline & $(0.0261)$ & $(0.0185)$ & $(0.0168)$ & $(0.0221)$ & $(0.0220)$ \\
\hline \multirow[t]{2}{*}{ Size of the bank } & & $0.1895^{* * *}$ & $0.1694^{* * *}$ & $0.1689^{* * *}$ & $0.1691^{* * *}$ \\
\hline & & $(0.0087)$ & $(0.0042)$ & $(0.0046)$ & $(0.0045)$ \\
\hline \multirow[t]{2}{*}{ Percentage of non performing loans } & & & $0.0341^{* * *}$ & $0.0343^{* * *}$ & $0.0340^{* * *}$ \\
\hline & & & $(0.0014)$ & $(0.0014)$ & $(0.0014)$ \\
\hline \multirow[t]{2}{*}{ Concentration of loans (HHI) } & & & $2.8282^{* * *}$ & $3.2309^{* * *}$ & $2.9066^{* * *}$ \\
\hline & & & $(0.4835)$ & $(0.4297)$ & $(0.4958)$ \\
\hline \multirow[t]{2}{*}{ Concentration of loans if State $_{k, t}=1$} & & & & $-0.8756^{* * *}$ & $-0.8685^{* * *}$ \\
\hline & & & & $(0.3341)$ & $(0.3322)$ \\
\hline \multirow[t]{2}{*}{ Size of the firm } & & & & & $-0.2648^{* * *}$ \\
\hline & & & & & $(0.0065)$ \\
\hline \multirow[t]{2}{*}{ Score of the firm } & & & & & $0.0335^{* * *}$ \\
\hline & & & & & $(0.0077)$ \\
\hline Firm fixed effect & yes & yes & yes & yes & yes \\
\hline Time fixed effect & yes & yes & yes & yes & yes \\
\hline Observations & 97,792 & 97,792 & 97,760 & 97,760 & 97,760 \\
\hline Adjusted R-squared & 0.407 & 0.420 & 0.425 & 0.423 & 0.427 \\
\hline \multicolumn{6}{|l|}{$\mathrm{p}$-value of F-test for total } \\
\hline effect equal to zero & 0.0000 & 0.0000 & 0.0000 & 0.0000 & 0.0000 \\
\hline
\end{tabular}




\begin{tabular}{|c|c|c|c|}
\hline & $(1)$ & $(2)$ & $(3)$ \\
\hline State $_{k, t}$ & $\begin{array}{c}-0.4402^{* * *} \\
(0.0220)\end{array}$ & $\begin{array}{c}-0.4382^{* * *} \\
(0.0225)\end{array}$ & $\begin{array}{c}-0.4373^{* * *} \\
(0.0220)\end{array}$ \\
\hline Size of the bank & $\begin{array}{c}0.1690^{* * *} \\
(0.0045)\end{array}$ & $\begin{array}{c}0.1691^{* * *} \\
(0.0045)\end{array}$ & $\begin{array}{c}0.1691^{* * *} \\
(0.0045)\end{array}$ \\
\hline Percentage of non performing loans & $\begin{array}{c}0.0340^{* * *} \\
(0.0014)\end{array}$ & $\begin{array}{c}0.0340^{* * *} \\
(0.0014)\end{array}$ & $\begin{array}{c}0.0340^{* * *} \\
(0.0014)\end{array}$ \\
\hline Concentration of loans (HHI) & $\begin{array}{c}2.9151^{* * *} \\
(0.4914)\end{array}$ & $\begin{array}{c}2.9104^{* * *} \\
(0.4976)\end{array}$ & $\begin{array}{c}2.9071^{* * *} \\
(0.4946)\end{array}$ \\
\hline Concentration of loans if the bank is state-owned & $\begin{array}{c}-0.8838^{* * *} \\
(0.3284)\end{array}$ & $\begin{array}{c}-0.8751^{* * *} \\
(0.3258)\end{array}$ & $\begin{array}{c}-0.8672^{* * *} \\
(0.3323)\end{array}$ \\
\hline Size of the firm & $\begin{array}{c}-0.2646^{* * *} \\
(0.0065)\end{array}$ & $\begin{array}{c}-0.2647^{* * *} \\
(0.0066)\end{array}$ & $\begin{array}{c}-0.2649^{* * *} \\
(0.0064)\end{array}$ \\
\hline Score of the firm & $\begin{array}{c}0.0335^{* * *} \\
(0.0076)\end{array}$ & $\begin{array}{c}0.0335^{* * *} \\
(0.0076)\end{array}$ & $\begin{array}{c}0.0334^{* * *} \\
(0.0077)\end{array}$ \\
\hline State $_{k, t}=1$ if the firm has more than $8 \%$ of credit line usage & $\begin{array}{c}0.0150 \\
(0.0127)\end{array}$ & & \\
\hline State $_{k, t}=1$ if the firm has more than $15 \%$ of credit line usage & & $\begin{array}{c}0.0214 \\
(0.0303)\end{array}$ & \\
\hline State $_{k, t}=1$ if the firm has more than $37 \%$ of credit line usage & & & $\begin{array}{l}-0.0364 \\
(0.0456)\end{array}$ \\
\hline Firm fixed effect & yes & yes & yes \\
\hline Time fixed effect & yes & yes & yes \\
\hline Observations & 97760 & 97760 & 97760 \\
\hline Adjusted R-squared & 0.427 & 0.427 & 0.427 \\
\hline $\mathrm{p}$-value of F-test for total & & & \\
\hline effect equal to zero & 0.0000 & 0.0000 & 0.0000 \\
\hline
\end{tabular}


Table 5:

\section{Differences in interest rates charged by state-owned and privately owned banks}

I define the interest rate as the ratio of the quarterly payment (interest plus fees) paid by the firm to the bank to its quarterly average balance minus the prime rate. In the second column, the interest rate refers to the subsample of companies borrowing from state-owned banks; in the third column, to the companies borrowing from privately owned banks. The difference is the average difference between the second column (interest rates charged by state-owned banks) and the third column (interest rates charged by privately owned banks). North includes the following regions: Piedmont, Valle d'Aosta, Lombardy, Trentino, Veneto, Friuli Venezia Giulia, Liguria, and Emilia Romagna. Center includes Tuscany, Umbria, Marche, and Lazio. South includes Abruzzo Molise, Campania, Puglia, Basilicata, Calabria, Sicily, and Sardinia. For the difference, I test statistical significance using the $t$-statistic with reference to a mean of zero. ${ }^{* * *}$ indicates statistically significant at the 1 -percent level, ${ }^{* *}$ indicates statistically significant at the 5-percent level.

\begin{tabular}{|c|c|c|c|c|}
\hline Interest rate-prime: & State-owned banks & Privately owned banks & Difference & Obs.. \\
\hline \multicolumn{5}{|c|}{ Borrowers classified by geographical location: } \\
\hline North & 3.03 & 3.22 & $-.18 * * *$ & 38,786 \\
\hline Center & 3.02 & 3.41 & $-.39 * * *$ & 6,292 \\
\hline South & 3.20 & 3.65 & $-.45 * * *$ & 3,818 \\
\hline \multicolumn{5}{|l|}{ Borrowers classified by size: } \\
\hline First quintile in sales & 3.70 & 3.86 & $-.16 * * *$ & 9,780 \\
\hline Second quintile in sales & 3.34 & 3.55 & $-.21 * * *$ & 9,778 \\
\hline Third quintile in sales & 3.12 & 3.36 & $-.24 * * *$ & 9,780 \\
\hline Fourth quintile in sales & 2.84 & 3.10 & $-.25^{* * *}$ & 9,780 \\
\hline Fifth quintile in sales & 2.23 & 2.51 & $-.28 * * *$ & 9,778 \\
\hline All borrowers & 3.05 & 3.27 & $-.23 * * *$ & 48,896 \\
\hline
\end{tabular}


Table 6:

\section{Interest rates charged by state-owned and privately owned banks in different areas}

The dependent variable is the interest rate charged to firm $i$ by bank $k$ at time $t$ minus the prime rate at time $t . S T A T E_{k, t}$ is a dummy variable equal to one if at time $t$ bank $k$ is a state-owned bank. North includes the following regions: Piedmont, Valle d'Aosta, Lombardy, Trentino, Veneto, Friuli Venezia Giulia, Liguria, and Emilia Romagna. Center includes Tuscany, Umbria, Marche, and Lazio. South includes Abruzzo Molise, Campania, Puglia, Basilicata, Calabria, Sicily, and Sardinia. I measure the size of the bank by logarithm of total assets. The percentage of nonperforming loans is the ratio of nonperforming loans over total loans. I measure market concentration at the province level by the Herfindahl-Hirschman Index (HHI) on total banking lending. Size of the firm is the logarithm of sales. All regressions include year and firm dummies. Heteroskedasticity robust standard errors are in brackets. The standard errors are corrected for within-year clustering. The table also reports the p-value of an F-test for the hypothesis that the joint effect of all the variables equals zero. 


\begin{tabular}{|c|c|c|c|c|c|}
\hline & $(1)$ & $(2)$ & $(3)$ & $(4)$ & $(5)$ \\
\hline \multirow{2}{*}{ State $_{k, t}$} & $-0.1806^{* * *}$ & $-0.4102^{* * *}$ & $-0.4490 * * *$ & $-0.4562 * * *$ & $-0.4566^{* * *}$ \\
\hline & $(0.0231)$ & $(0.0195)$ & $(0.0143)$ & $(0.0203)$ & $(0.0202)$ \\
\hline \multirow[t]{2}{*}{ State if firm is located in the South } & $-0.2709 * * *$ & $-0.2370^{* * *}$ & $-0.3097 * * *$ & $-0.3132^{* * *}$ & $-0.3143^{* * *}$ \\
\hline & $(0.0401)$ & $(0.0683)$ & $(0.0365)$ & $(0.0370)$ & $(0.0365)$ \\
\hline \multirow[t]{2}{*}{ State if firm is located in the North } & $-0.2137 * * *$ & $-0.1501 * * *$ & $-0.1814^{* * *}$ & $-0.1818^{* * *}$ & $-0.1815^{* * *}$ \\
\hline & $(0.0112)$ & $(0.0123)$ & $(0.0145)$ & $(0.0154)$ & $(0.0154)$ \\
\hline \multirow[t]{2}{*}{ Size of the bank } & & $0.1870^{* * *}$ & $0.1655^{* * *}$ & $0.1655^{* * *}$ & $0.1657^{* * *}$ \\
\hline & & $(0.0097)$ & $(0.0058)$ & $(0.0057)$ & $(0.0056)$ \\
\hline \multirow[t]{2}{*}{ Percentage of non performing loans } & & & $0.0356^{* * *}$ & $0.0356^{* * *}$ & $0.0353^{* * *}$ \\
\hline & & & $(0.0016)$ & $(0.0016)$ & $(0.0016)$ \\
\hline \multirow[t]{2}{*}{ Concentration of loans (HHI) } & & & $2.7801^{* * *}$ & $2.7296^{* * *}$ & $2.4032^{* * *}$ \\
\hline & & & $(0.4705)$ & $(0.4473)$ & $(0.5120)$ \\
\hline \multirow[t]{2}{*}{ Concentration of loans if State $_{k, t}=1$} & & & & 0.1093 & 0.1200 \\
\hline & & & & $(0.3012)$ & $(0.2977)$ \\
\hline \multirow[t]{2}{*}{ Size of the firm } & & & & & $-0.2652^{* * *}$ \\
\hline & & & & & $(0.0064)$ \\
\hline \multirow[t]{2}{*}{ Score of the firm } & & & & & $0.0334^{* * *}$ \\
\hline & & & & & $(0.0076)$ \\
\hline Firm fixed effect & yes & yes & yes & yes & yes \\
\hline Time fixed effect & yes & yes & yes & yes & yes \\
\hline Observations & 97,792 & 97,792 & 97,760 & 97,760 & 97,760 \\
\hline Adjusted R-squared & 0.408 & 0.420 & 0.426 & 0.426 & 0.428 \\
\hline \multicolumn{6}{|l|}{ p-value of F-test for total } \\
\hline effect equal to zero & 0.0000 & 0.0000 & 0.0000 & 0.0000 & 0.0000 \\
\hline
\end{tabular}


Table 7:

\section{Interest rates charged by state-owned and privately owned banks by firms' size}

The dependent variable is the interest rate charged to firm $i$ by bank $k$ at time $t$ minus the prime rate at time $t$. STATE $E_{k, t}$ is a dummy variable equal to one if at time $t$ bank $k$ is a state-owned bank. I measure the size of the bank by logarithm of total assets. The percentage of nonperforming loans is the ratio of nonperforming loans over total loans. I measure market concentration at the province level by the Herfindahl-Hirschman Index (HHI) on total banking lending. Size of the firm is the logarithm of sales. All the regressions include year and firm dummies. Heteroskedasticity robust standard errors are in brackets. The standard errors are corrected for within-year clustering. The table also reports the p-value of an F-test for the hypothesis that the joint effect of all the variables equals zero. 


\begin{tabular}{|c|c|c|c|c|c|}
\hline & (1) & $(2)$ & $(3)$ & $(4)$ & $(5)$ \\
\hline \multirow[t]{2}{*}{ State $_{k, t}$} & $-0.2965^{* * *}$ & $-0.5151^{* * *}$ & $-0.5703^{* * *}$ & $-0.4937 * * *$ & $-0.4792^{* * *}$ \\
\hline & $(0.0301)$ & $(0.0427)$ & $(0.0324)$ & $(0.0321)$ & $(0.0323)$ \\
\hline \multirow[t]{2}{*}{ State $_{k, t}$ if firm in smallest size quintile } & $0.1906^{* * *}$ & $0.1868^{* * *}$ & $0.2006^{* * *}$ & $0.2113^{* * *}$ & $0.1582^{* * *}$ \\
\hline & $(0.0366)$ & $(0.0338)$ & $(0.0380)$ & $(0.0377)$ & $(0.0391)$ \\
\hline \multirow[t]{2}{*}{ State $_{k, t}$ if firm in second size quintile } & $0.0933^{* *}$ & $0.0899 * *$ & $0.1038^{* *}$ & $0.1104^{* *}$ & $0.0859^{* *}$ \\
\hline & $(0.0419)$ & $(0.0411)$ & $(0.0443)$ & $(0.0446)$ & $(0.0417)$ \\
\hline \multirow{2}{*}{ State $_{k, t}$ if firm in third size quintile } & 0.0466 & 0.0396 & 0.0483 & 0.0536 & 0.0359 \\
\hline & $(0.0431)$ & $(0.0398)$ & $(0.0412)$ & $(0.0413)$ & $(0.0401)$ \\
\hline \multirow[t]{2}{*}{ State $_{k, t}$ if firm in fourth size quintile } & 0.0287 & 0.0272 & 0.0320 & 0.0356 & 0.0258 \\
\hline & $(0.0253)$ & $(0.0231)$ & $(0.0241)$ & $(0.0242)$ & $(0.0237)$ \\
\hline \multirow[t]{2}{*}{ Size of the bank } & & $0.1894^{* * *}$ & $0.1692^{* * *}$ & $0.1684^{* * *}$ & $0.1688^{* * *}$ \\
\hline & & $(0.0085)$ & $(0.0040)$ & $(0.0044)$ & $(0.0043)$ \\
\hline \multirow[t]{2}{*}{ Percentage of non performing loans } & & & $0.0344^{* * *}$ & $0.0346^{* * *}$ & $0.0342^{* * *}$ \\
\hline & & & $(0.0013)$ & $(0.0013)$ & $(0.0013)$ \\
\hline \multirow[t]{2}{*}{ Concentration of loans (HHI) } & & & $2.8206^{* * *}$ & $3.3630^{* * *}$ & $3.0251^{* * *}$ \\
\hline & & & $(0.4919)$ & $(0.4608)$ & $(0.5301)$ \\
\hline \multirow[t]{2}{*}{ Concentration of loans if State $_{k, t}=1$} & & & & $-1.1806^{* * *}$ & $-1.0980^{* * *}$ \\
\hline & & & & $(0.3375)$ & $(0.3233)$ \\
\hline \multirow[t]{2}{*}{ Size of the firm } & & & & & $-0.2476^{* * *}$ \\
\hline & & & & & $(0.0078)$ \\
\hline \multirow[t]{2}{*}{ Score of the firm } & & & & & $0.0334^{* * *}$ \\
\hline & & & & & $(0.0076)$ \\
\hline Firm fixed effect & yes & yes & yes & yes & yes \\
\hline Time fixed effect & yes & yes & yes & yes & yes \\
\hline Observations & 97,792 & 97,792 & 97,760 & 97,760 & 97,760 \\
\hline Adjusted R-squared & 0.407 & 0.420 & 0.425 & 0.425 & 0.427 \\
\hline
\end{tabular}


Table 8:

\section{Electoral results, party affiliation and interest rates charged by state-owned banks}

The dependent variable is the interest rate charged to firm $i$ by bank $k$ at time $t$ minus the prime rate at time $t$. I measure the local political strength of the party by the percentage of votes received by the party to which the chairperson of the state-owned bank is affiliated in the area where the firm is borrowing. I measure the size of the bank by logarithm of total assets. The percentage of nonperforming loans is the ratio of non-performing loans over total loans. I measure market concentration at the province level by the Herfindahl-Hirschman Index (HHI) on total banking lending. Size of the firm is the logarithm of sales. All the regressions include year and firm dummies. Heteroskedasticity robust standard errors are in brackets. The standard errors are corrected for within-year clustering. The table also reports the p-value of an F-test for the hypothesis that the joint effect of all the variables equals zero. Column 1 sample includes all the observations (state-owned-banks-firm-year) for which political affiliation of the president of the state-owned bank is available. Column 2 is the same sample, excluding years 1994 and 1995. Columns 3 and 4 include only loans from national state-owned banks. 


\begin{tabular}{lcccc}
\hline \hline & $(1)$ & $(2)$ & $(3)$ & $(4)$ \\
Local political strength of the party & $-0.2001^{* *}$ & $-0.2295^{* * *}$ & $-0.3240^{* * *}$ & $-0.2837^{* * *}$ \\
& $(0.0806)$ & $(0.0844)$ & $(0.1239)$ & $(0.1005)$ \\
Size of the bank & $0.1702^{* * *}$ & $0.1641^{* * *}$ & $0.1282^{* * *}$ & \\
& $(0.0065)$ & $(0.0033)$ & $(0.0237)$ & \\
Percentage of non performing loans & $0.0303^{* * *}$ & $0.0230^{* * *}$ & $0.0206^{* * *}$ & \\
& $(0.0045)$ & $(0.0030)$ & $(0.0061)$ & \\
Concentration of loans (HHI) & $7.3368^{* * *}$ & $8.0807^{* * *}$ & $7.9113^{* * *}$ & $7.7236^{* * *}$ \\
& $(1.2113)$ & $(0.7930)$ & $(0.7298)$ & $(0.7004)$ \\
Size of the firm & $-0.3744^{* * *}$ & $-0.3277^{* * *}$ & $-0.3432^{* * *}$ & $-0.3435^{* * *}$ \\
Score of the firm & $(0.0742)$ & $(0.0690)$ & $(0.0853)$ & $(0.0849)$ \\
Time fixed effect & $0.0321^{* * *}$ & $0.0328^{* *}$ & 0.0258 & 0.0258 \\
Firm fixed effect & $(0.0087)$ & $(0.0144)$ & $(0.0167)$ & $(0.0167)$ \\
yes & yes & yes & yes \\
Bank fixed effect & & & & yes \\
Observations & yes & yes & yes & yes \\
Adjusted R-squared & no & no & no & \\
\hline \hline
\end{tabular}




\section{References}

Alesina, Alberto, Stephan Danninger, and Massimo V. Rostagno 1999, "Redistribution through Public Employment: The Case of Italy", NBER WP 6746,

Altman, Edward I., 1968, "Financial Ratios, Discriminant Analysis and the Prediction of Corporate Bankruptcy", Journal of Finance, 23: 589-609.

Altman, Edward I., 1993, Corporate financial distress and bankruptcy, John Wiley and Sons, New York.

Altman, Edward I., Marco Giancarlo, and Varetto Franco, 1994, "Corporate distress diagnosis: Comparisons using linear discriminant analysis and neural networks (the Italian experience)", Journal of Banking and Finance, 18: 505-529.

Atkinson, A. B., And Joseph E. Stiglitz, 1980, Lectures on Public Economics, London, McGraw Hill..

BAneRJee, ABhiJit 1997, "A Theory of Misgovernance", Quarterly Journal of Economics, 112: 1289-1332.

Barca, Fabrizio and Sandro Trento, 1996, "State-ownership and the evolution of Italian corporate governance", mimeo.

Barth, James R., Gerard Caprio, Jr. and Ross Levine, 2000, "Banking Systems Around the Globe: Do Regulation and Ownership Affect Performance and Stability? ", Working Paper 2325, World Bank.

Berger, Allen N., and Timothy H. Hannan, 1989, "The Price-Concentration Relationship in Banking", Review of Economics and Statistics, 71: 291-99.

De Bonis, RiccARdo, 1998, "Public sector banks in Italy: past and present", mimeo.

Detragiache, Enrica, Paolo G. Garella, and Luigi Guiso, 2000, "Multiple versus Single Banking Relationship", Journal of Finance, 55: 1133-1161. 
Golden, Miriam, 2001, "The Effects of the Personal Vote on Political Patronage, Bureaucracy and Legislation in Postwar Italy ", working paper, Department of Political Science, UCLA.

Ginsborg, Paul, 1990, A history of contemporary Italy: society and politics, 1943-1988, Penguin Books, London.

Greenwald, Bruce, And Joseph E. Stiglitz, 1986, "Externalities in Economies with Imperfect Information and Incomplete Markets", Quarterly Journal of Economics, 101: 229-64.

Hannan, Tiмотнy H., 1997, "Market Share Inequality, the Number of Competitors, and the HHI: An Examination of Bank Pricing", Review of Industrial Organization 12: 23-35.

Hart, Oliver, Andrei Shleifer, And Robert Vishny 1997, "The Proper Scope of Government: Theory and an Application to Prisons", Quarterly Journal of Economics, 112: 11271162.

La Porta, Rafael, Florencio Lopez-de-Silanes, Andrei Shleifer and Robert Vishny, 2002, "Government ownership of banks", Journal of Finance, 57(1):256-301.

LAFFont, Jean-Jacques, 1993, "Comments on "Public versus Regulated Enterprise", by Willig, Proceedings of the World Bank Annual Conference on Economic Development, Washington D.C. International Bank for Reconstruction and Development/World Bank., 175-178

Laffont, Jean-Jacques And Jean Tirole, 1993, A Theory of Incentives in Regulation and Procurement, MIT Press, Cambridge, MA.

Lopez-De-Silanes, Florencio, Andrei Shleifer and Robert Vishny, 1997, "Privatization in the United States", Rand Journal of Economics, 28(3):447-471.

Martiny, Mario, And Carmelo Salleo, 1997, "The Efficiency of Italian Banks: Some Empirical Evidence", mimeo.

Mayer, Colin, 2000, "Financial Systems, Corporate Finance, and Economic Development", in R.G. Hubbard (ed.) Asymmetric Information, Corporate Finance and Investment (pp.307332). Chicago:University of Chicago Press. 
Pagano, Marco, Fabio Panetta, And Luigi Zingales, 1998, "Why Do Companies Go Public? An Empirical Analysis", Journal of Finance, 53: 27-64.

Rajan, Raghuram and Luigi Zingales, 1998, "Financial Dependence and Growth", American Economic Review, 88(3): 559-586.

SAPienza, PaOla, 2002, "The Effect of Banking Mergers on Loan Contracts", Journal of Finance, $57(1): 329-368$

Shleifer, Andrei, 1998, "State versus Private Ownership", Journal of Economic Perspectives.

Shleifer, Andrei And Robert W. Vishny, 1994, "Politicians and Firms", Quarterly Journal of Economics, 109: 995-1025.

Shleifer, Andrei And Robert W. Vishny, 1998, The Grabbing Hand: Government Pathologies and Their Cures, Harvard University Press, Cambridge, MA.

Stiglitz, Joseph E., 1993, "The role of the state in Financial Markets", Proceedings of the World Bank Annual Conference on Economic Development, Washington D.C. International Bank for Reconstruction and Development/World Bank, pp. 19-56.

Stiglitz, Joseph E., And Andrew Weiss, 1981, "Credit Rationing in Markets with Imperfect Information", American Economic Review, 71: 393-410.

Tirole, Jean, 1989, The Theory of Industrial Organization, The MIT Press, Cambridge, Massachusetts.

Tirole, JeAn, 1994, "The Internal Organization of Governments", Oxford Economic Papers, 46: $1-29$.

Visentini, Gustavo, 2000, "Mixed and Market Oriented Economies: the Italian Situation", Mimeo, Universita' Luiss Guido Carli, Rome, Italy. 


\section{Appendix I}

\section{Diagnostic System}

The company data contain a numerical score for the firms in the sample that describes the risk profile of the firm following Altman $(1968,1993)$. Both state- and privately owned banks had access to the numerical score at the time when they lent to the firms. The score was obtained by $\mathrm{CB}$ using two discriminant functions. This score express the "risk profile" of the business. A detailed description of the methodology used by $\mathrm{CB}$ to calculate the numerical score is in Altman et al. (1994). I used the score to classify the companies into seven zones: high security, security, vulnerability, high vulnerability, uncertainty between vulnerability and risk, risk of bankruptcy; and high risk of bankruptcy. The table below describe the risk profile of the companies contained in my sample borrowing from state- and privately owned banks. By construction, the risk profile is identical in the two sub-samples, thus only one table is included.

Table A.1.

\begin{tabular}{cccc}
\hline \hline SCORE & Frequency & Percent & Cumulative Frequency \\
\hline High security & 1,420 & 2.6 & 1,420 \\
Security & 15,262 & 27.6 & 16,682 \\
Vulnerability & 409 & .7 & 17,091 \\
High vulnerability & 11,743 & 21.2 & 28,834 \\
Uncertainty between vulnerability and risk & 13,471 & 24.3 & 42,305 \\
Risk of bankruptcy & 10,472 & 18.9 & 52,777 \\
High risk of bankruptcy & 2,616 & 4.7 & 55,393 \\
\hline \hline
\end{tabular}




\section{Appendix II}

\section{Electoral results and party affiliation in banks}

Historically, the Italian political system has been a multi-party system. Until 1994, both chambers (The Senate of the Republic and the Chamber of Deputies) were elected on a proportional basis. Voters cast ballots both for parties and for candidates within those parties. Seats were divided up according to the proportion of the total vote each party received. Parties would allocate their seats to candidates based on how many votes each received in his district. Since no single party could ever count on winning a straight majority of seats in Parliament, majority rule has depended on party alliances and coalitions. After 1994, the electoral system of the Senate was changed to a mixed system with a simple majority vote for 75 percent of the seats and a proportional representation (d'Hondt method) on the basis of regional voting results for remaining 25 percent.

For each party affiliated with the state-owned banks, I have collected electoral results for the Chamber of Deputies from three national elections, 1987, 1992, and 1994. I use the Chamber of Deputies electoral results because the electoral system did not change over the sample period. During those years, no single party controlled a majority of seats in either chamber of the Italian Parliament. I collect the data at the provincial level.

I collect appointments of the chairpersons of state-owned banks from newspapers. Overall, in my sample the affiliation of the chairperson is linked to 5 different parties. The main one, the Christian Democrats, made appointments to 29 banks in the sample. The second most influential party, the Italian Socialist Party, made appointments to nine banks in the sample, both the Italian Liberal Party and the Social Democratic Party made appointments to two banks, while and National Alliance made appointments to only one bank.

Table A.2. shows the electoral results for these five parties in the provinces where they lent money to the firms in my sample. Panel A presents results for 1987 elections, Panel B for 1992 elections, and Panel C for 1994 elections. For example, banks affiliated to the socialist party lent money in 1992 and 1993 (Panel B) to firms located in 91 provinces. 
Table A.2.

A: 1987 election

\begin{tabular}{|l|c|c|c|c|c|}
\hline \hline & mean & $\mathrm{sd}$ & $\min$ & $\max$ & Number of provinces \\
Christian Democrats & .34565932 & .08607512 & .08375919 & .52429986 & 80 \\
Socialist Party & .13883011 & .028753 & .06012196 & .20933744 & 89 \\
Italian Liberal Party & .02274278 & .01556027 & .00539812 & .09755591 & 52 \\
Social Democratic Party & .02849019 & .01601734 & .00475035 & .09887846 & 71 \\
\hline \hline & \multicolumn{7}{|c|}{$\mathrm{B}: 1992$ election } \\
\hline \hline \multicolumn{7}{|c|}{ mean } & sd & $\min$ & $\max$ & Number of provinces \\
\hline Christian Democrats & .30600768 & .09383184 & .07377624 & .51638401 & 89 \\
Socialist Party & .13649238 & .03488646 & .04451371 & .26654419 & 91 \\
Italian Liberal Party & .02806362 & .01906862 & .01006228 & .13501064 & 70 \\
Social Democratic Party & .02611314 & .01770669 & .00560963 & .07984234 & 76 \\
\hline \hline
\end{tabular}

C: 1994 election

\begin{tabular}{|l|c|c|c|c|c|}
\hline \hline & mean & $\mathrm{sd}$ & $\min$ & $\max$ & Number of provinces \\
\hline Socialist Party & .0183175 & .0066557 & .0094487 & .0324773 & 33 \\
National Alliance & .1293044 & .0635202 & .0404381 & .2955712 & 66 \\
\hline \hline
\end{tabular}

